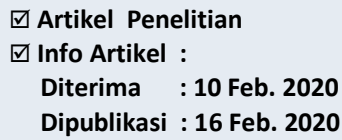

\title{
Dukungan Keluarga Berhubungan dengan Kepatuhan Pasien Gagal Ginjal Kronik yang Menjalani Terapi Hemodialisa di RSUD dr. M. HAULUSSY Ambon
}

\author{
Dene Fries Sumah ${ }^{1 凶}$ \\ 1Universitas Kristen Indonesia Maluku Program Studi Keperawatan. Ambon. Indonesia, \\ Email : ristoisfrisco_peea@yahoo.com \\ Korespondensi : Dene Fries Sumah, Universitas Kristen Indonesia Maluku, Ambon, Indonesia, \\ Email : ristoisfrisco_peea@yahoo.com
}

\begin{abstract}
ABSTRAK.
Penelitian bertujuan ini untuk mengetahui hubungan antara dukungan keluarga dengan kepatuhan pasien gagal ginjal kronik yang menjalani hemodialisa. Observasional analitik adalah metode yang digunakan dengan pendekatan potong lintang (cross sectional). Populasi penelitian adalah semua pasien gagal ginjal kronik yang menjalani terapi hemodialisa di Ruang Hemodialisa RSUD dr. M. Haulussy Ambon yang berjumlah 85 orang dengan sampel sebanyak 46 responden dan teknik Accidental sampling dengan analisa data menggunakan uji statistik chi-square. Hasil penelitian di dapat bahwa dari 46 responden, 60,9\% patuh menjalani hemodialisa serta dukungan keluarga pada pasien gagal ginjal kronik yang menjalani hemodialisa menunjukan bahwa ada hubungan yang bermakna antara dukungan keluarga dengan kepatuhan pasien gagal ginjal kronik yang menjalani terapi hemodialisa dengan nilai (p-value 0,000).
\end{abstract}

\section{Keyword: Dukungan Keluarga, Kepatuhan Terapi Hemodialisa, Gagal Ginjal Kronik}

\section{PENDAHULUAN}

Gagal ginjal kronik (GGK) adalah gangguan fungsi renal yang progresif dan irreversibel dimana kemampuan tubuh gagal untuk mempertahankan metabolisme dan keseimbangan cairan dan elektrolit, akibat destruksi struktur ginjal progresif dengan manifestasi penumpukan sisa metabolik (toksik uremik) di dalam darah (Rahayu, 2018). World Health Organization (2015) menyebutkan pertumbuhan jumlah penderita GGK pada tahun 2014 telah meningkat $50 \%$ dari tahun sebelumnya dan menjadi masalah besar di dunia karena sulit disembuhkan. Angka kematian GGK sebesar 850.000 orang setiap tahunnya dan merupakan peringkat ke-12 kematian di dunia (Organization, 2015). Berdasarkan data Riset Kesehatan Dasar, penderita gagal ginjal kronik sesuai diagnosa dokter di Indonesia sebesar 3,8\% atau berjumlah 713.783 jiwa, dengan prevalensi tertinggi di provinsi Jawa Barat berjumlah 131.846 jiwa, diikuti oleh Jawa Timur 113.045 jiwa, sedangkan di daerah Maluku, diketahui penderita gagal ginjal kronik yang berumur lebih dari 30 tahun menurut gejala di Maluku dengan prevalensi $0,6 \%$ dengan jumlah sebesar 4.351 jiwa (RIKESDAS), 2018). Adapun penanganan GGK dibagi dalam dua tahapan yaitu penanganan konservatif dan terapi pengganti ginjal. Penanganan konservatif dapat ditempuh dengan obat-obatan, diet dan kontrol yang teratur. Sedangkan terapi pengganti ginjal terdiri dari Hemodialisis, peritoneal dialisis, dan transplantasi ginjal (Wagiyo, 2016).

Hemodialisa adalah terapi yang berfungsi untuk menggantikan kerja ginjal dalam mengeluarkan zat-zat sisa metabolisme atau racun tertentu dari peredaran darah manusia seperti air, natrium, kalium, hidrogen, urea, kreatinin, asam urat, dan zat-zat lain melalui membran semi permeabel sebagai pemisah darah dan cairan dialisat pada ginjal buatan dimana terjadi proses difusi, osmosis dan ultra filtrasi (Larasati, 2018). Frekuensi tindakan terapi hemodialisa rutin 2 kali dalam seminggu dan membutuhkan waktu pelaksanaan hemodialisa selama 4 sampai 5 jam setiap kali terapi. (Ipo dkk, 2016). Hemodialisa dapat mencegah kematian, namun tidak dapat menyembuhkan penyakit GGK sehingga menyebabkan pasien harus patuh menjalani hemodialisa. Kepatuhan terapi hemodialisa merupakan hal yang penting untuk diperhatikan, karena jika pasien tidak patuh akan terjadi penumpukan zat-zat berbahaya dari tubuh hasil metabolisme dalam darah (Puspasari dkk, 2018).

Kepatuhan pasien sangat diperlukan untuk keberhasilan terapi hemodialisa. Kepatuhan adalah perilaku seseorang yang tertuju terhadap intruksi atau petunjuk yang ditentukan baik itu jadwal pengobatan, mengikuti diet, dan atau melaksanakan perubahan gaya hidup sesuai dengan rekomendasi pemberi pelayanan kesehatan. Kepatuhan pasien dapat dipengaruhi oleh beberapa 
faktor yaitu pendidikan, lamanya hemodialisa, pengetahuan tentang hemodialisa, motivasi, akses pelayanan kesehatan, dukungan keluarga dan persepsi pasien terhadap peran perawat sebagai edukator. Kepatuhan pasien diartikan sebagai sejauh mana perilaku pasien sesuai dengan ketentuan yang diberikan oleh profesional kesehatan (Arditawati, 2013). Keluarga diharuskan mampu mengatasi masalah yang di hadapi pasien dan untuk mendorong pasien patuh melakukan terapi secara teratur. karena keluarga merupakan sumber dukungan terbesar bagi pasien untuk dapat memberikan motivasi serta dukungan kepada pasien (Kim, 2014). Dukungan keluarga adalah keikutsertaan keluarga untuk memberikan bantuan dalam bentuk dukungan keluarga yaitu dukungan emosional yang melibatkan ekspresi cinta, kepercayaan dan perhatian pada orang lain. Dukungan keluarga dapat diwujudkan dengan pemberian perhatian, bersikap empati, memberikan dorongan, memberikan saran memberikan pengetahuan dan lainnya yang mampu meningkatkan psikologis pasien (Suryaningsih, 2013).

Hal ini dapat dibuktikan dengan hasil penelitian Fatmawati (2014), dengan judul Hubungan dukungann keluarga dan sikap perawat dengan kepatuhan pasien gagal ginjal kronik dalam menjalani terapi hemodialisa di RSUD Dr. Soedarso Pontianak, menunjukan bahwa 18,8\% pasien gagal ginjal kronik yang tidak patuh menjalani hemodialisa diantaranya 4 pasien memiliki dukungan keluarga baik dan 5 pasien memiliki dukungan keluarga kurang baik dari hasil penelitian ini menunjukan ada hubungan yang bermakna antara dukungan keluarga dengan kepatuhan pasien gagal ginjal kronik yang menjalani terapi hemodialisa.

Berdasarkan hasil wawancara yang dilakukan pada 8 orang pasien didapati keterangan bahwa pasien memiliki dukungan keluarga kurang baik hal ini karena keluarga memiliki kesibukan pekerjaan yang tidak bisa ditinggalkan. Keluarga hanya mengantar pasien saat pertama kali menjalani terapi hemodialisa dan keluarga berfikir ini sudah menjadi rutinitas yang selalu di jalani pasien. Pasien juga mengatakan selama hemodialisa perawat tidak pernah berinisiatif untuk memberikan informasi mengenai perubahan pada tubuh pasien selama menjalani hemodialisa, sedangkan 2 orang pasien mengatakan selama terapi hemodialisa keluarga selalu mengingatkan pasien mengenai jadwal terapi dan selama hemodialisa keluarga selalu mendampingi pasien bahkan menyediakan makanan rendah garam sesuai dengan anjuran dokter.

Ada pun tujuan dari penelitian ini yakni: untuk menganalisis apakah ada hubungan dukungan keluarga dengan kepatuhan pasien gagal ginjal kronik yang menjalani terapi hemodialisa di RSUD dr. M. Haulussy Ambon.

\section{METODE PENELITIAN}

Desain penelitian yang digunakan dalam penelitian ini adalah penelitian Observasional analitik dengan pendekatan Cross Sectional (Potong Lintang) yang dimana variabel independen dan variabel dependen diukur secara bersamaan (Notoatmodjo, 2012).

Populasi dalam penelitian ini adalah seluruh pasien yang menjalani terapi hemodialisa di RSUD dr. M. Haulussy Ambon berjumlah 85 Orang. Teknik pengambilan sampel dilakukan dengan metode Accidental sampling yaitu teknik penentuan sampel berdasarkan kebetulan/incidental bertemu dengan peneliti dapat digunakan sebagai sampel, bila dipandang orang yang kebetulan ditemui itu cocok dengan sumber data (Sugiyono,2013). Kriteria sampel yang digunakan adalah pasien GGK yang menjalani terapi hemodialisa yang dalam keadaan sadar, bisa baca tulis dan bersedia menjadi responden. Sedangkan pasien dengan penurunan kesadaran, pasien yang mengalami gangguan retinopati dan yang tidak bersedia menjadi responden tidak diikutsertakan menjadi sampel dalam penelitian. Jadi besar sampel dalam penelitian ini adalah 46 responden.

Variabel dalam penelitian ini terdiri dari variabel bebas (Independen) dan variabel terikat (dependen). Variabel bebas dalam penelitian ini adalah dukungan keluarga sedangkan variabel terikat dalam penelitian ini adalah kepatuhan pasien yang menjalani terapi hemodialisa.

Instrumen yang digunakan dalam penelitian ini berupa kuesioner mengenai data demografi pasien, dukungan keluarga pasien, dan kepatuhan pasien dalam menjalani hemodialisa. Kuesioner dukungan keluarga diambil dari penelitian Nursalam (2015) dengan 10 pertanyaan, dan Kuesioner kepatuhan hemodialisa dengan 6 pertanyaan di ambil dari penelitian Azwar (2013). Penelitian ini dilakukan di unit hemodialisa RSUD dr. M. Haulussy Ambon.

Teknik analisa data menggunakan analisis univariat (Analisis Deskriptif) bertujuan untuk menjelaskan atau mendeskripsikan karakteristik setiap variabel yang di duga ada hubungan atau 
berkolerasi. Pada Chi Square diolah dengan menggunakan komputerisasi program SPSS versi 24.0 dengan tingkat signifikan $\mathrm{a}=0,01$.

\section{HASIL DAN PEMBAHASAN}

\subsection{Analisis Univariat}

Tabel 1. Distribusi Frekuensi Responden Berdasarkan Umur, Jenis Kelamin, Pendidikan, Pekerjaan, Status Perkawinan, Jadwal Terapi Hemodialisa, Dukungan keluarga, dan Kepatuhan menjalani Hemodialisa di Ruang Hemodialisa RSUD dr. M. Haulussy Ambon.

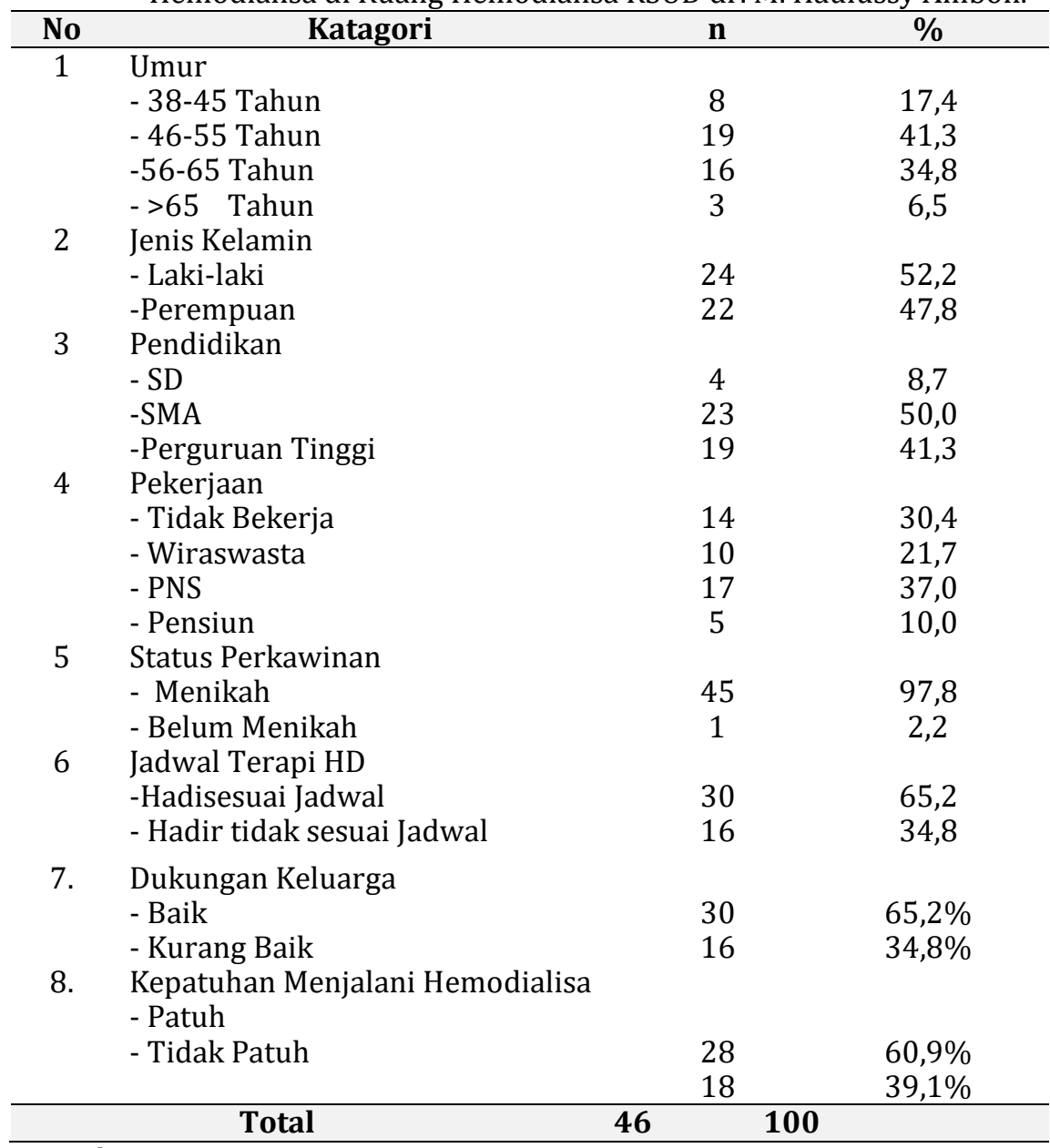

Sumber : Data Primer, 2019

\subsection{Analisis Bivariat}

Tabel 2. Hubungan Antara Dukungan Keluarga Dengan Kepatuhan Menjalani Hemodialisa Di Ruang Hemodialisa RSUD dr. M. Haulussy Ambon.

\begin{tabular}{lcccccccc}
\hline & \multicolumn{4}{c}{$\begin{array}{c}\text { Kepatuhan Menjalani } \\
\text { Hemaodialisa }\end{array}$} & \multirow{2}{*}{ Total } & \multirow{2}{*}{ p-value } \\
\cline { 2 - 7 } & Patuh & \multicolumn{4}{c}{ Tidak Patuh } & & \\
\cline { 2 - 7 } & $\mathbf{n}$ & $\mathbf{\%}$ & $\mathbf{n}$ & $\mathbf{\%}$ & $\mathbf{n}$ & $\mathbf{\%}$ & \\
\hline Baik & 26 & 86,7 & 4 & 13,3 & 30 & 100 & \\
Kurang Baik & 2 & 12,5 & 14 & 87,5 & 16 & 100 & \\
\hline Total & $\mathbf{2 8}$ & $\mathbf{6 0 , 9}$ & $\mathbf{1 8}$ & $\mathbf{3 9 , 1}$ & $\mathbf{4 6}$ & $\mathbf{1 0 0}$ & \\
\hline
\end{tabular}

Berdasarkan tabel 2 dari 46 responden diperoleh 30 responden yang memiliki dukungan keluarga baik sebagian besar patuh dalam menjalani hemodialisa sejumlah 26 orang (86,7\%). Sedangkan responden dengan dukungan keluarga kurang baik sejumlah 16 orang sebagian besar tidak patuh dalam menjalani hemodialisa sejumlah 14 orang $(87,5 \%)$. Hal ini dibuktikan dengan menggunakan uji chi-square diperoleh nilai $\mathrm{p}$-value sebesar $0,000(\mathrm{p}<0,01)$ artinya Ho ditolak maka 
dapat disimpulkan bahwa ada hubungan yang signifikan antara dukungan keluarga dengan kepatuhan menjalani hemodialisa di ruang Hemodialisa Rumah Sakit RSUD dr. M. Haulussy Ambon 2019

\subsection{PEMBAHASAN}

\section{Dukungan Keluarga}

Hasil penelitian menyatakan bahwa dari 46 responden, hampir seluruhnya $(65,2 \%)$ memiliki dukungan keluarga yang baik dan hanya $(34,8 \%)$ yang memiliki dukungan keluarga kurang baik. Hal ini sejalan dengan penelitian yang dilakukan oleh anita (2012) mengenai gambaran dukungan keluarga pada pasien gagal ginjal dalam menjalani hemodialisa di RSUD kota semarang yang menunjukan bahwa dukungan keluarga pasien sebagian besar baik. hasil penelitian menunjukan masih ada pasien yang tidak mendapat dukungan yang baik dari keluarga, hal ini dapat disebabkan keluarga pasien yang merasa pasien masih mampu untuk melakukan terapi hemodialisa secara mandiri sehngga tidak perlu didampingi atau diantar oleh keluarga. Selain itu juga dapat disebabkan karena keluarga yang sibuk bekerja sehingga tidak dapat mendampingi selama proses hemodialisa. Pasien yang tidak dapat dukungan keluarga yang baik dapat juga dikarenakan keluarga tinggal di luar kota sehingga sulit untuk mengontrol, menemani, atau bahkan mangantar pasien dalam melakukan terapi hemodialsia. Dukungan keluarga menjadi faktor yang sangat berpengaruh dalam menentukan keyakinan dan nilai kesehatan individu serta dapat menentukan program pengobatan yang dapat mereka terima. Selain itu, keluarga juga memberi dukungan dan membuat keputusan mengenai perawatan dari anggota keluarga yang sakit. (Niven, 2012). DeChesnay dan Magnuson menyatakan bahwa cara keluarga klien dalam menggunakan pelayanan kesehatan biasanya akan mempengaruhi cara klien dalam melakukan kesehatan. Keluarga yang sehat biasanya akan mencari cara untuk membantu seluruh anggota keluarganya mencapai potensi mereka yang paling besar (Perry \& Potter, 2015).

\section{Kepatuhan Pasien Menjalani Hemodialisa}

Dalam penelitian ini, kepatuhan didefenisikan sebagai periaku responden dalam menjalani terapi hemodialsia secara rutin sesuai dengan jadwal yang telah ditentukan dan tidak mundur 3 hari dari jadwal yang telah di tentukan. Pasien yang pernah mundur 3 hari atau lebih dari jadwal yang telah ditentukan dikatagorikan kedalam pasien yang tidak patuh.

Hasil penelitian menunjukan bahwa dari 46 responden, hampir seluruhnya (60,9\%) patuh dalam menjalani terapi hemodialisa secara rutin sesuai jadwal yang telah ditentukan, hanya sebagian kecil $(39,1 \%)$ yang tidak patuh dalam menjalani terapi hemodialisa. Hal ini dapat dipengaruhi oleh dukungan keluarga yang baik $(65,2 \%)$ dan peran perawat sebagai edukator baik $(67,4 \%)$ yang mendukung pasien untuk patuh menjalani hemodialisa secara teratur $(80,6 \%)$.

Hasil penelitian ini sejalan dengan hasil penelitian yang dilakukan oleh Syamsiyah (2011) yang menyatakan bahwa pasien gangguan gagal gijal yang menjalani hemodialisa sebagian besar patuh, yaitu sebanyak (60,9\%). Penelitian ini juga sejalan dengan dengan penelitian yang dilakukan Dewi, (2011) tentang hubungan antara dukungan keluarga, pengetahuan dan sikap dengan kepatuhan menjalani hemodialisa pada pasien gagal ginjal kronikdi Rumah sakit Telogorejo semarang yang menunjukan hasil bahwa kepatuhan dalam menjalani hemodialisa pada pasien GGK di Rumah Sakit Telogorejo Semarang sebagian tergolong patuh, yaitu sebanyak 56,3\%).

Meskipun sebagian bear pasien GGK sudah patuh menjalani terapi hemodialisa, namun masih ada pasien yang tidak patuh. Pasien tidak melakukan terapi hemodialisa secara teratur sesuai jadwal disebabkan karena pasien merasa tubuhnya masih merasa nyaman sehingga merasa dapat bertahan untuk tidak melakukan terapi hemodialisa di rumah sakit yang jaraknya cukup jauh dari tempat tinggal. Selain itu, pasien tidak dapat melakukan terapi hemodialisasesuai jadwal dikarenakan pasien memiliki kesibukan pekerjaan sehingga melewati hari untuk melakukan terapi. hemodialisa pada pasien GGK sangatlah penting, karena jika tidak melakukan terapi hemodialisa secara teratur akan terjadi penumpukan zat sisa metabolisme yang berbahaya bagi tubuh jika tidak segera dikeluarkan dari tubuh penderita GGK.

\section{Hubungan Dukungan Keluarga Dengan Kepatuhan Menjalani Hemodialisa Di RSUD dr. M. Haulussy Ambon.}

Berdasarkan output hasil analisis bivariat dengan menggunakan uji chi-Square untuk variabel hubungan dukungan keluarga dengan kepatuhan menjalani hemodialisa, di peroleh nilai p-value 
sebesar 0,000 $(p<0,01)$. Maka dapat disimpulkan bahwa Ho di tolak dan Ha di terima yang artinya ada hubungan yang signifikan antara hubungan dukungan keluarga dan kepatuhan menjalani hemodialisa. Hasil penelitian ini menunjukan bahwa sebagian besar responden memiliki dukungan keluarga baik sejumlah 30 orang $(65,2)$ dan patuh dalam melakukan hemodialisa berjumlah 26 orang $(86,7 \%)$. Temuan dalam hasil penelitian ini mendukung konsep keluarga sebagai salah satu faktor eksternal yang memiliki hubungan paling kuat dengan pasien. Keberadaan keluarga mampu memberikan motivasi yang sangat bermakna pada pasien disaat pasien memiliki berbagai permasalahan perubahan pola kehidupan yang demikian rumit, menjenuhkan dengan segala macam program kesehatan (Rosidin, 2016).

Menurut teori Magnusom dalam jurnal Fatmawati (2014) menyatakan bahwa cara keluarga klien dalam menggunakan pelayanan kesehatan biasanya akan mempengaruhi cara klien dalam melaksanakan kesehatan. Keluarga yang sehat biasanya akan mencari cara untuk membantu seluruh anggota keluarganya mencapai potensi mereka yang paling besar. Hasil penelitian ini sejalan dengan penelitian yang dilakukan oleh Sidiq (2014), menyimpulkan bahwa ada hubungan antara dukungan keluarga dengan kualitas hidup penderita penyakit gagal ginjal tahap akhir yang menjalani terapi hemodialisa di badan layanan umum daerah RSUD dr. Zainoel Abidin Banda Aceh dengan nilai p-value $0,000(p<0,05)$. Dari hasil penelitian menunjukan bahwa, masih terdapat responden yang memiliki dukungan keluarga yang kurang baik berjumlah 16 orang $(34,8)$ sebagian besar tidak patuh dalam menjalani hemodialisa berjumlah 14 orang $(87,5 \%)$. Hal ini disebabkan karena keluarga yang sibuk bekerja sehingga tidak mempunyai waktu untuk mendampingi pasien selama proses hemodialisa. Pasien yang tidak mendapatkan dukungan keluarga baik dapat juga dikarenakan keluarga yang tinggal berjauhan dengan pasien hemodialisa sehingga sulit untuk mengontrol, menemani, atau bahkan mengantar pasien dalam melakukan terapi hemodialisa. Peneliti berasumsi bahwa dukungan keluarga merupakan faktor yang dapat mempengaruhi kepatuhan pasien gagal ginjal kronik untuk menjalani proses terapi hemodialisa.

\section{PENUTUP}

Hasil penelitian didapat bahwa ada hubungan antara dukungan keluarga dengan kepatuhan pasien gagal ginjal kronik yang menjalani hemodialisa di RSUD dr. M. Haulussy Ambon dibuktikan dengan hasil Uji Chi Square ( $\mathrm{p}=0,000$ atau $\mathrm{p}<0,01)$. Saran yang dapat diberikan adalah perawat ruangan hemodialisa dapat memberikan perhatian, motivasi dan edukasi kesehatan kepada pasien dan keluarga sehingga dapat memulihkan atau memelihara kesehatan, serta peneliti selanjutnya perlu melakukan penelitian dengan variabel berbeda seperti hubungan pengetahuan dengan kepatuhan menjalani hemodialisa, hubungan motivasi pasien dengan kepatuhan menjalani hemodialisa.

\section{DAFTAR PUSTAKA}

Ariani, d. S., 2016. Stop Gagal Ginjal Dan Gangguan Gangguan Ginjal Lainnya. Jakarta: Gramedia.

Arditawati., 2013. pengaruh pendidikan kesehatan terhadap kepatuhan pasien CKD untuk mempertahankan kualitas hidup di RSUD Pandanarang Boyolali.

Erick Johans Manoppo Gresty M. Masi Wico Silolonga. (2018). Hubungan Peran Perawat Sebagai Edukator Dengan Kepatuhan Penatalaksanaan Hipertensi Di Puskesmas Tahuna Timur. 6(1).

Fresenius Medical care \& Co., 2013. Keperawatan medikal bedah. Padang: Djamil.

Ipo, Aryani \& Suri., 2018. Hubungan frekuensi hemodialisis dengan tingkat stres pada pasien gagal ginjal kronikyang menjalani terapi hemodialisis. Jurnal Keperawatan Silampari (JKS), Volume 1(No 2), 140-153.

Kim., 2014. Testing the psychometric properties in patients receiving in-center hemodialysis. nephrology nursing journa, 377-393. 
Larasati., 2018. Hubungan Dukungan Keluarga Dengan Tingkat Kecemasan Pasien Gagal Ginjal Kronik Yang Menjalani Hemodialisa Di Rumah Sakit Dr Moewardi Surakarta. Skripsi, (hal. 1-11).

Notoatmodjo, S., 2012. Metodologi penelitian kesehatan. Jakarta: Rineka cipta.

Puspitasari., 2015. Gambaran dukungan keluarga pada pasien gagal ginjal kronik yang menjalani hemodialisa di ruang hemodialisa Di Rumah Sakit Dr Moewardi Surakart. Skripsi.

Rahayu, Ramlis \& Fernando,. 2018. Hubungan frekuensi hemodialisis dengan tingkat stres pada pasien gagal ginjal kronikyang menjalani terapi hemodialisis. Jurnal Keperawatan Silampari (JKS), Volume 1(No 2), 140-153.

Riset Kesehatan Dasar (RIKESDAS)., 2018. Laporan Hasil Riset Kesehatan Dasar.

Wagiyo., 2016. Hubungan jenis kelamin dan frekuensi hemodialisa dengan kualitas hidup pasien gagal ginjal kronik yang menjalani hemodialisa di rumah sakit umum daerah raden matther jambi. Jurnal akademik baiturrahim, Volume 5(No 2), 47.

World Health Organization., 2015. Global Chronic Renal Failure Report 2014. Switzerland: World Health Organization 